\title{
Love as Seeing in Truth: Sartre and Stein on Self-Constitution
}

\author{
Chase J. Cloutier \\ Boston College School of Theology and Ministry (Brighton, MA)
}

\begin{abstract}
Realizing who I am and who I am called to be depends in part on my relation to others. Others empathizing with me significantly impacts my self-understanding and character formation. The possibility of a positive encounter is vital because of its role in self-constitution. Both Jean-Paul Sartre and Edith Stein recognized the great import of the gaze of another in the realization of one's own personhood and personal development. However, due to different appraisals of the meaning of human life, Stein evaluates the ultimate import of intersubjective experience as positive whereas Sartre deems it negative. Sartre characterizes interpersonal relations as necessarily combative and conflictual: in order to realize one's full stature and freedom, one must objectify the other so as to escape the other's dominating look. For Sartre the only look one can receive is a look of hatred which attacks and steals one's dignity. On the other hand, Stein proposes that the look of the other has the power to reveal the true and full potential of the self, even counteracting false self-appraisal. A look or attitude of love from another can reveal one's capacity for virtue and initiate one along this path of virtue. In order to overcome the wounds of cultural commodification of the person, we must approach one another in love. Though Sartre offers a particularly incisive diagnosis of "fallen" intersubjectivity and interpersonal relations of objectification, Stein's thought can work to correct and complete his insights on the look of the other, offering a basis for understanding "redeemed" interpersonal relationships in a civilization of love.
\end{abstract}

\section{Text}

\section{Introduction}

How others see me significantly impacts my own self-understanding and character formation. Indeed, the other plays a pivotal role in the constitution of oneself. Both Jean-Paul Sartre and Edith Stein recognized the great consequence of the gaze of the other. However, due to their vastly different appraisals of being, they diverge in explicating the ultimate importance of intersubjective experience. 


\section{CLOUTIER: LOVE AS SEEING}

On the one hand, Sartre characterizes interpersonal relations as necessarily combative and conflictual: in order to realize one's full stature and freedom, one must objectify the other person to escape their dominating look. For Sartre the only intersubjective look possible is a look of hatred which attacks and degrades one's dignity. I see this analysis as a particularly incisive diagnosis of "fallen" intersubjectivity. In contrast, Stein proposes that the look of the other has the power to reveal one's true and full potential, even counteracting false self-appraisal. This understanding of empathy suggests a Look of Love, an attitude appreciative of present goodness and hidden potential, which can reveal one's capacity for virtue and initiate one along the path toward greater moral perfection. I contend that this look constitutes a "redeemed" understanding of interpersonal relationships.

\section{Sartre on Personal Ontology and Intersubjectivity}

Sartre's existential ontology divides all of being into two categories: beingin-itself which lacks consciousness and being-for-itself which has consciousness. ${ }^{1}$ Being-in-itself is material, non-conscious being which has no interior reflection on itself, e.g. a stone, a tree, a chair. They have no sentience or self-awareness. These objects are utterly identical with themselves. There can be no separation between consciousness and the object of consciousness. Thus, for Sartre being-in-itself is complete; it cannot change unlike conscious being which is in constant flux. ${ }^{2}$,

When it comes to being-for-itself, Sartre holds that conscious beings are aware of themselves; they have a conscious presence. There is a basic split in their being between what they are and their consciousness of themselves. There is a mix of being and non-being which allows for the possibility of change. ${ }^{3}$ The possibility of freedom is opened up in the tension between what I am now and what I can become. Thus, there is a sense in which being-for-itself is incomplete-not yet secure, not yet in full possession of itself. Still the conscious being-for-itself longs to attain the status of non-conscious being-in-itself. It longs to be one thing- to be itself without change. Being-for-itself has the disadvantage, in Sartre's view, of the

1. This is based on a disjunction between the subject and the phenomena that the subject perceives. c.f. Klaus Hartmann, Sartre's Ontology (Evanston: Northwestern University Press, 1966) 33: "The resulting division of beings (existents) is into subjective being and the being of phenomena. Sartre's ontology is based on this disjunction."

2. Gabriel Marcel, "Existence and Human Freedom" in The Philosophy of Existentialism (New York: Citadel Press, 1956) 60: "Being-in-itself, he tells us, is completely full of itself, it is purely and simply what it is; it has no inwardness and, consequently, no potentiality and no future. It can never be in the relation of 'other' to another being..." This sense of "perfection" is not to be taken in a Thomistic sense, as Sartre places much more weight on the subjective experience than on traditional ontological categories. c.f. Hartmann, Sartre's Ontology, 38: "Being-in-itself involves no principles like essence and existence, causing it to be finite, determinate beings."

3. Marcel, "Existence and Human Freedom," 61: "It is of the essence of conscious being to be what it is not and not to be what it is." 


\section{CLOUTIER: LOVE AS SEEING}

complexity of consciousness which is an obstacle to the simplicity of being.

In order to understand what meaning attaches to being in Sartre's philosophy, we must explore a third class of being which he posits: being-forothers. I exist in a world that is inhabited by other subjects. However, they are necessarily mediated to me through material bodies, which are objects. Is it possible then to encounter the other as subject? ${ }^{4}$ For Sartre, there is only one kind of encounter possible in which a subject is revealed: The Look. I only realize that another subject exists under their oppressive gaze. They look upon me and I am reduced to their narrow objectification of me. I am shamed, realizing that I am an object. I am confronted with the combative gaze of the other. I am pierced and shaken to my depths. This self of mine, visible to another, is something utterly inaccessible to me, precisely in the dimension of being an object. The other is partially constitutive of my being. That is, the other partially founds my ontological structure..$^{5}$ My freedom as a subject is constricted in that my possibilities are negated by the objectifying gaze of the other. Their judgment about who I am and who I can become limits my potential. My being is compromised and lessened: my own self-realization and self-constitution is hindered.

In Sartre's worldview, the meaning of my being is established by my own self-assertion and creation. I seek absolute freedom to determine my own being and the meaning of my life. I desire to create the meaning of my life within the confines of this freedom. However, the presence of the other is a threat to my freedom. Their objectifying gaze threatens to defeat my freedom by the imposition of their judgment. But through the triumph of my freedom over the other's, I attain absolute meaning for my being. Yet insofar as I am still being-for-itself, I am limited by the possibility of this changing. I may potentially lose this stature I have built up for myself if the other steals it. Thus, inter-subjectivity is essentially conflictual for Sartre. ${ }^{6}$ I am forever on the defensive against the attack of the other's gaze. Sartre's approach has been called a fallen intersubjectivity because of its focus on the danger of objectification. Under his system there is no positive dimension to intersubjectivity, though he remains open to the idea of such a redemption of encounter. ${ }^{7}$ The fallenness of his system is, perhaps, most potently illustrated by

4. Jean-Paul Sartre, Being and Nothingness, trans. Hazel E. Barnes (New York: Washington Square Press, 1956) 304: "realism provides no place for the intuition of the Other." Sartre follows Descartes in positing a sharp differentiation between extended material being and non-extended spiritual being. For Sartre the spatially simple consciousness of the Other cannot be communicated through materiality.

5. Sartre, Being and Nothingness, 302, 475. 302: "the Other has not only revealed to me what I was; he has established me in a new type of being..." 475: "The Other holds a secret-the secret of what I am." others."

6. Sartre, Being and Nothingness, 475: "Conflict is the original meaning of being-for-

7. Sartre, Being and Nothingness, 534: "These considerations do not exclude the possibility of an ethics of deliverance and salvation. But this can be achieved only after a radical conversion 


\section{CLOUTIER: LOVE AS SEEING}

the famous line from his play No Exit: "Hell is other people." The Look of the other becomes a perpetually limiting and objectifying force counteracting my attempt to establish myself in being. One is condemned to the necessity of interpersonal relations, and the only choice one has is whether or not to fight back.

In order to deal with the consequences of this fallen intersubjectivity, man seeks out what Sartre identifies as coping mechanisms: love being a prime example. The ideal of love is held out for us and we desire to attain to this so-called miracle. The lover desires to fill the world of the beloved, wanting a certain exclusivity with the beloved. The notion that another loves me offers the forbidden hope of justifying my entire existence. The joy of love consists in just this: the meaning of my life has been realized. ${ }^{8}$ But in the end this ideal is said to be impossible; its value in the end is nugatory. ${ }^{9}$ For Sartre the reality of love is nothing else but an attempt to appropriate the other in seduction. One seeks to capture the other's gaze through seducing them precisely through being seen as an object. One aims to capture the freedom of the Other through deception: just at the moment when the other thinks they have freely chosen to look upon the beloved, the beloved achieves seduction and repurposes the Look of the other in order to enslave them. Throughout this process the one seducing ventures to make the other acknowledge that the seducer has a fullness of being. ${ }^{10}$ Again, this in no way respects the freedom of the other but seeks to chain it and redirect it to the seducer's own selfish purposes. This understanding of love does not attain to any real sense of mutuality or self-gift. It is reducible to the desire to seduce and to coerce the other to serve my freedom. ${ }^{11}$ To emphasize just how counterfeit a love like this truly is, it is necessary to indicate the other coping mechanisms which he places on par with love, namely, masochism and hatred.

Ultimately, for Sartre the only kind of look one may receive is a Look of hatred. From the viewpoint of the one being gazed upon, the only case in which the other is revealed as subject is the objectifying gaze. Once I sense the onslaught of the other's combative gaze, I realize that another subject exists and is attempting to steal my dignity and enslave my freedom. This is a Look which limits my freedom and inhibits my potential for growth. The one who looks cannot sympathize with me as a subject but necessarily relates to me as a mere object. In this setting true

\footnotetext{
which we cannot discuss here."

8. Sartre, Being and Nothingness, 484: "This is the basis for the joy of love when there is joy; we feel that our existence is justified."

9. Gabriel Marcel, "Existence and Human Freedom," 75: "the miracle of successful love...this ideal is regarded as utterly unattainable."

10. Sartre, Being and Nothingness, 484: "By seduction I aim at constituting myself as a fullness of being and at making myself recognized as such."

11. Sartre, Being and Nothingness, 484: "the lover must seduce the beloved, and his love can in no way be distinguished from the enterprise of seduction."
} 


\section{CLOUTIER: LOVE AS SEEING}

community is impossible. ${ }^{12}$ While the name of love is attached to one form of this gaze, it is clear that love cannot exist where I am perceived merely as object, where I am enslaved, where my dignity is stolen. Love is reduced to a pathetic and doomed attempt to incapacitate the attacker. When put in this light, one can realize that love in the Sartrian sense is just hatred taken under the aspect of seduction. The project of love is nothing other than risking objectification so as to appropriate the other for my own ends.

\section{Stein on Personal Ontology and Intersubjectivity}

It is striking that both Sartre and Stein sought to establish a personal ontology through an existential phenomenological exploration of the human person. They were operating under common influences such as Descartes, Husserl, and Heidegger. However, when it comes down to the ultimate significance of being and what it means to achieve being in its perfection, Stein departs drastically from Sartre. One could attribute this to her being influenced by Thomistic metaphysics.

At the root of Stein's metaphysical worldview is her understanding of act and potency. In this regard she is both faithful to her Thomistic roots and dynamic in further developing these basic ontological principles phenomenologically. In exploring the human person, she considered the incompleteness of personal being. Similar to Sartre, she even discusses this in terms of being and non-being. ${ }^{13} \mathrm{We}$ are not yet fully established in our being. There is being and non-being in us. But what is the meaning of this non-being? As revealed by our experience of personal change across time, it is clear that certain dimensions of our being are actual and others are potential at any given time. Through time we actualize certain traits and others may fall back into potentiality. However, there is a real sense in which those aspects which are only potential are still contained within our being. My capabilities are part of who I am in the present. ${ }^{14}$ Otherwise, it does not seem possible that these aspects could become actualized.

Furthermore, for Stein the development of personal being which we all experience is not rooted in the constructive creation of meaning but in the realization of the meaning of being itself. While Sartre thinks that the project of my being is the attainment of absolute value in an unfettered freedom, Stein sees the project of my being as striving towards the perfection of my being through the realization of my being's true meaning. The actualization of my personal being is

12. Marcel, "Existence and Human Freedom," 76: "the whole of this dialectic...rests upon the complete denial of we as subject, that is to say upon the denial of communion.

13. Stein, Finite and Eternal Being, trans. Kurt F. Reinhardt (Washington, DC: ICS Publications, 2002), 37: "When I turned toward being as it is in itself, it revels to me a dual aspect: that of being and that of not-being."

14. Stein, Finite and Eternal Being, 41: "Whatever human beings do is a realization of what they are capable of doing; and what they are capable of doing is a manifestation of what they are." 


\section{CLOUTIER: LOVE AS SEEING}

also the development of my personality toward perfection. ${ }^{15}$ This is based upon Stein's appropriation of the Thomistic notion of essence or nature in terms of the person. Every individual being has a specified nature with an orientation toward perfection. In the actualization of an individual being's nature, this being is brought to a higher level of ontological excellence, brought closer toward its fullness. ${ }^{16}$ For Stein, a being is good at least insofar as it exists, i.e., insofar as it participates in being itself. Similarly, personal being is good insofar as it is actualized, participating in the fullness of being. I am not a self-made man, creating my own value by securing my freedom to act arbitrarily, as could be taken from Sartre's view. Rather, I am a man with personal capacities that stand to be fulfilled by the fullest development of talent and virtue. I am capable of and inclined toward clear knowledge and ardent love, but I must actualize these powers in virtue if I am to progress along the way of perfection.

On the basis of this personal ontology, we may proceed to understand Stein's notion of self-constitution under the look of the other. In her doctoral dissertation On the Problem of Empathy, Stein considers the way in which another's empathizing with me helps to constitute who I am. First, there is a sense in which the image of my own body is only given to me in totality once I take into account the way in which another views me. I originally experience my body as Leibe, i.e. I live the body from within. But over time, seeing other human persons and relating to their body as a physical object (Körper), I realize that others see me in the same objective way. I am both this body lived from within as well as that body which others see. ${ }^{17}$ Thus, I come to a notion of myself as a unity of subjectively lived body and objectively physical body. ${ }^{18}$

But there is a sense in which the awareness of my own personality and personal development is dependent upon the attitude others take toward me. I grow in knowledge of myself precisely through realizing the attitude of another. ${ }^{19}$ Central to this phenomenon is the reiterated empathic act, i.e., when I empathize with

15. Stein, Finite and Eternal Being, 34: "The transition from potency to act or - as we may not express it - from potential to actual being is not only a transition from one mode of being to another but from an inferior mode of being to a higher one."

16. Stein, Finite and Eternal Being, 41: "In the realization of their capabilities, their essence or nature reaches its highest ontological development."

17. Baseheart, Person in the World: An Introduction to the Philosophy of Edith Stein, (Dordrecht; Boston: Kluwer Academic, 1997), 36: "The body given in consciousness is sensed as 'living body' (Leib) in acts of inner perception and in acts of outer perception. It is outwardly perceived as physical body (Körper) of the outer world. This double givenness is experienced as the same body."

18. MacIntyre, Edith Stein: A Philosophical Prologue, 1913-1922 (New York: Rowman \& Littlefield Publishers, 2006), 83: "through reiterated empathy I become aware of myself as others are aware of me and so understand my physical body as one and the same as the living body of my lived experience."

19. Baseheart, Person in the World, 38: "Empathy is...an important aid in the person's acquisition of self knowledge." 


\section{CLOUTIER: LOVE AS SEEING}

someone empathizing with me. I realize my own true feeling and disposition by empathizing with the other who sees me. Part of the truth of my being lies hidden until I empathize with another. ${ }^{20}$ When the other empathizes with me, there are three possibilities with respect to their vision of my being: a) the other sees in truth something that I am aware of, b) the other falsely sees something I know not to be the case, or c) the other sees in truth something that I falsely thought to be otherwise. For our purposes the most interesting cases are 'b' and 'c' above, the cases of deception.

Though formulated in a way that Sartre would find unsatisfactory, 'b' is the case which most closely parallels the Sartrian Look. When a subject turns his gaze toward another subject, if he sees merely a threat to his own independent freedom, he has failed to see the full significance of the other person. The subject who objectifies all others has attempted to reduce the other to something which they in truth are not. For example, if an oppressive male chauvinist has an attitude of objectification toward a woman in his life, he attempts to impose a false image upon her being. He seeks to tear down her being, enslaving her as it were and robbing her of her dignity. This attitude may impact her own subjective self-realization and hinder her progress in personal development toward perfection. If she takes his attitude as the end-all be-all denotation of her being, it will be more difficult for her to see her true worth and meaning. For Sartre, this is a normal instantiation of intersubjective relations. We necessarily compete with each other to achieve absolute meaning for our being through securing our freedom over another's freedom. The only option for this oppressed woman according to Sartre is to retaliate either by rejecting the Look of the male chauvinist or by capturing his gaze in seduction only to warp his freedom to her purposes. In other words, the only feasible response is hatred (though not much is thereby accomplished). But, as we shall see, Stein would not answer in the same way.

In case 'c' above, i.e., when the other sees something in me that I did not know about myself, we have the basis for overcoming false images we have of ourselves. The example Stein gives is a recognition of some fault of ourselves: If I look around for praise after showing kindness to another, one who notices this about me might have a clearer awareness of my ulterior motive than I do. ${ }^{21}$ In other words the other may have greater clarity concerning my interior character than I do. They may be a better judge of it than I am, at least in specific cases. ${ }^{22}$ This can be when I have some fault, or it may be the case when I have some potential or talent that I

20. MacIntyre, Edith Stein: A Philosophical Prologue, 85: "I know myself then in part only as I know and am known by others."

21. Stein, On the Problem of Empathy, trans. Waltraut Stein (Washington, DC: ICS Publications, 1989) 89.

22. Stein, On the Problem of Empathy, 89: "It is possible for another to 'judge me more accurately' than I judge myself and give me clarity about myself" 


\section{CLOUTIER: LOVE AS SEEING}

do not know about myself. For instance, if I quickly stop to help a stranger to carry groceries to their car, my friend may notice my alacrity to serve more easily than I realize it about myself. Or if I am very patient and serve my elders at home without complaining, a friend may see this more clearly than I do myself. Stein sees empathy and inner perception working "hand in hand to give me myself to myself." 23 If the other makes a mistake in assessing my character, my inner perception may correct them, but it is also possible that the other's sight of me corrects a false self-appraisal. Consider individuals like the objectified woman, the under-appreciated son, and the unloved grandmother. Because they were not shown the necessary appreciation and attention, they might begin to take false images of themselves to heart. I suggest that the Look of Love can conquer these false images, founding a better self-appraisal. This Look of Love from the other has the power to overcome deceptions I may have about myself. ${ }^{24}$

\section{The Look of Love: Overcoming Sartrian Conflict}

On the basis of Stein's personal ontology and intersubjective selfconstitution, we may further posit, contra Sartre, that there exists a Look of Love through which false appraisals of the person may be defeated. To love is to will the good of the beloved and to have a disposition of appreciation for the goodness of the beloved. By seeing myself as the lover sees me, my own self-deceptions are brought to light. ${ }^{25}$ If I have a rather negative view of myself, believing that I am worthless or that the pursuit of perfection is hopeless or impossible for me, I have lost sight of the potential of my own being. The lover is able to see the meaning of my life more clearly than I do. They see that goodness which is already actualized in me as well the potential I have for even greater virtue. The lover says, "Fear not, my beloved. You are great and will do great things. See what I see.” By reflexively sympathizing with the lover, I am ennobled and brought to a new confidence and self-possession. Having seen my personal potential through their eyes, I no longer have low self-esteem. By presenting to me an intimation of my perfection, the lover moves me, encouraging me toward the actualization of my being. The deception of false images with which others have oppressed me, fall away.

Let us take for example one of the worst victims of the Sartrian Look: the veteran prostitute. Repeatedly she offers her services to men, expecting them to objectify her. Out of a desperate need for money, she willingly hands herself over

23. Stein, On the Problem of Empathy, 89, full quote: "This is how empathy and inner perception work hand in hand to give me myself to myself."

24. MacIntyre, Edith Stein: A Philosophical Prologue, 85: "I discover that I may be so deceived and what it is about which I am deceived by learning to view myself as someone else views me, by learning how I appear to someone who is empathetically aware of me."

25. Baseheart, Person in the World, 39: "The deceptive view of self may be corrected by seeing myself as I see another and as he/she sees me." 


\section{CLOUTIER: LOVE AS SEEING}

to the objectifying gaze and the oppressive freedom of another. She no longer believes she has any worth. The meaning of her existence has been reduced to that of an instrument of pleasure for others. Perhaps she has even attempted to cope with her situation by seducing certain other men in her life so as to coerce their freedom. Is there any hope for such a poor soul? Let us say that by some happy chance she finds a steady job and gets herself back on her feet. She still struggles with giving herself into a real relationship. She feels trapped in being an object for another. Yet one day she meets a man who treats her differently. He looks her in the eye and smiles encouragingly at her. They laugh at one another's jokes and enjoy being in one another's presence. Eventually they begin dating. The respect and love with which he approaches her is completely new in her life. Though it is very difficult and slow in coming, his constancy in affirming her and showing her reverence begins to change her own self-perception. Slowly but surely, she realizes the truth about herself - that she has dignity, she is beautiful, and she deserves to be treated as a valuable human being.

Indeed, under the gaze of love I realize my current virtue, I am awakened to the possibility of new growth, and I receive an intimation of my full being. First, I come to an awareness of the goodness already actualized in my being. The Look of Love affirms the value, the goodness of my existence as a human person in general but also as this particular human person. ${ }^{26}$ Love justifies my being because it is love which reveals to me the goodness of my being. ${ }^{27}$ Sartre was gravely mistaken in thinking this impossible; it is of the greatest existential importance. I need love in order to realize that my personal existence is justified and meaningful. The Look of Love awakens one to the truth of their identity. In a certain sense, I am not yet fully myself until I have had the Look of Love. This is seen in the increased frequency of developmental problems in children when they do not grow up in loving homes. Their fundamental worth, the goodness of their existence, has not been communicated to them.

Second, I am awakened to the possibility of new personal development. Contained within my being is a potential for growth. Even those aspects of my character which have not yet been actualized may be anticipated by the Look of the lover. In the rash man the lover sees the potential for courage. In the prodigal man, the potential for generosity. In the reserved man, the potential for reasoned reflection. Every kind of temperament has a general orientation toward virtue (and a need to curb the corresponding vice). Drawing on Max Scheler and Dietrich von

26. Baseheart, Person in the World, 40: "In the act of loving, one experiences a grasping or intending of the value of a person. One loves a person for his or her own sake."

27. Here it is helpful to quote Joseph Ratzinger in Principles of Catholic Theology: Building Stones for a Fundamental Theology (San Francisco: Ignatius Press, 1987) 80: "If an individual is to accept himself, someone must say to him: 'It is good that you exist' - must say it, not with words, but with that act of the entire being that we call love. For it is the way of love to will the other's existence and, at the same time, to bring that existence forth again." 


\section{CLOUTIER: LOVE AS SEEING}

Hildebrand to complement Edith Stein's theory of intersubjectivity, one can speak of the movement of love toward higher values in the beloved. The faults of the other are seen in light of the possible virtues that could be cultivated. Their true potential for virtue is most clearly seen by the lover.

Third, the ultimate vocation of the other is intimated through the Look of Love. Based on the value that the lover has seen in the beloved; a certain ideal structure of value is constructed which is thought to be in accord with the other's "true self." ${ }^{28}$ This is the deepest vision that love is granted into the essential being of the beloved. Some dimension of their ultimate vocation and perfection is revealed. Thus, based on some small deed a friend may say "you are going to make a good father one day." This is not so much limiting the beloved friend to a particular vocation or way of life as it is seeing a possible deeper perfection of their being.

\section{Synthesis and Conclusion}

Ultimately, while Sartre's approach to intersubjectivity offers an incisive look into the nature of objectification and its consequences, it fails to perceive and explicate the ultimate significance and meaning of the human person. Because of Sartre's fundamentally flawed personal ontology (seeing personal potential as something one is condemned to), he could not grasp the full role of intersubjectivity in self-constitution. Drawing on Edith Stein's understanding of personal ontology and intersubjectivity, we have shown that the Look of Love is a force for the deeper actualization of the person. A proper account of act and potency in the human person allows for an objective meaning of personal ontology: one which stands to be fulfilled or compromised in individual cases. The Sartrian Look is that intersubjective stance which most grossly violates the dignity and freedom of the human person. But all intersubjective relations are not condemned to this conflict. Through the Look of Love false self-images can be overcome. It is under the gaze of love that the human person becomes aware of their value, potential, and vocation. Thus, in the end, we come to the truth of who we are and of who we are called to be, not in isolation but in community. One necessary aspect of my full selfconstitution is an attitude of love from another, and in the end, from God.

28. Max Scheler, The Nature of Sympathy, trans. Peter Heath (New Brunswick: Transaction Publishers, 2009) 154, 157. 154: "love invariably sets up, as it were, an 'idealized' paradigm of value for the person actually present, albeit conceiving this at the same time as an embodiment of his 'true' nature and 'real' value, which only awaits confirmation in feeling." 157: "true love opens our spiritual eyes to ever-higher values in the object loved." 


\section{CLOUTIER: LOVE AS SEEING}

\section{Bibliography}

Baseheart, Person in the World: An Introduction to the Philosophy of Edith Stein. Dordrecht; Boston: Kluwer Academic, 1997.

MacIntyre, Alastair. Edith Stein: A Philosophical Prologue, 1913-1922. New York: Rowman \& Littlefield Publishers, 2006.

Marcel, Gabriel. "Existence and Human Freedom" in The Philosophy of Existentialism. New York: Citadel Press, 1956.

Sartre, Jean-Paul. Being and Nothingness. Translated by Hazel E. Barnes. New York: Washington Square Press, 1956.

Scheler, Max. The Nature of Sympathy. Translated by Peter Heath. New Brunswick: Transaction Publishers, 2009.

Stein, Edith. Finite and Eternal Being. Translated by Kurt F. Reinhardt. Washington, DC: ICS Publications, 2002.

. On the Problem of Empathy. Translated by Waltraut Stein. Washington, DC: ICS Publications, 1989. 